\title{
LIVRO ELETRÔNICO E SUA UTILIZAÇÃO POR ALUNOS DE GRADUAÇÃO DE UMMA UNIVERSIDADE FEDERAL
}

\author{
LIBRO ELECTRÓNICO Y SU USO POR \\ ESTUDIANTES UNIVERSITARIOS DE UNA \\ UNIVERSIDAD FEDERAL
}

\begin{abstract}
Adriana Bogliolo Sirihal Duarte - bogliolo@eci.ufmg.br Doutora em Ciência da Informação pela Universidade Federal de Minas Gerais (UFMG). Professora da Escola de Ciência da Informação da UFMG

Aline de Queiroz Lopes - line_ql@hotmail.com Mestranda em Ciência da Informação pela Universidade Federal de Minas Gerais (UFMG). Bibliotecária do Centro de Documentação da Rede Globo Minas de Televisão.
\end{abstract}

\begin{abstract}
RESUMO
Introdução: Os livros eletrônicos (e-books) vem ganhando notoriedade no mercado e na pesquisa acadêmica. As bibliotecas universitárias apostam no empréstimo de conteúdos, e não acreditam no empréstimo dos dispositivos para sua leitura.

Objetivos: Apresenta os resultados de pesquisa realizada junto aos alunos de graduação e bibliotecários do Sistema de Bibliotecas da Universidade Federal de Minas Gerais - UFMG visando investigar como os estudantes estão utilizando livros eletrônicos e se o sistema de bibliotecas está preparado para oferecer apoio em termos de serviços e acervo.

Metodologia: Quanto à metodologia, a pesquisa realizou-se em três etapas compreendendo revisão de literatura, pesquisa qualitativa com bibliotecários (condução de entrevistas) e pesquisa quantitativa com estudantes (aplicação de questionários).

Resultados: Os principais resultados demonstram que mais de $50 \%$ dos alunos já fizeram uso de livros eletrônicos, mas cerca de $75 \%$ preferem o livro impresso para realizar suas atividades de leitura e de pesquisa. $O$ principal formato utilizado é o PDF e as funcionalidades mais utilizadas incluem alterar o tamanho da fonte, grifar, consultar dicionário e fazer anotações. A oferta de e-books pelo Sistema de Bibliotecas da UFMG ainda é incipiente e ocorre de forma não coordenada, através de iniciativas isoladas por unidades. Os bibliotecários apontam vantagens e desvantagens no uso do livro eletrônico.
\end{abstract}


Conclusões: O público não tem demandado mais do que é oferecido. Podendo escolher, a grande preferência do leitor da UFMG ainda é pelo livro no formato impresso.

Palavras-chave: Livro eletrônico. E-book. Biblioteca universitária. Sistema de Bibliotecas da Universidade Federal de Minas Gerais.

\title{
1 INTRODUÇÃO
}

$\mathrm{Na}$ era das novas tecnologias, surgem os e-books, ou livros eletrônicos, cuja conceituação vem sendo discutida. Segundo Wilson e Landoni (2001), a definição de livros eletrônicos engloba três diferentes aspectos, a saber: a) dispositivos de hardware que permitem aos leitores acessarem conteúdos; b) aplicações de software, usadas para visualizar conteúdo online e; c) o conteúdo que é visualizado através de um dispositivo de hardware ou de aplicações de software. Atualmente os dispositivos de hardware não são mais denominados de e-books ou livros eletrônicos, mas recebem a denominação específica de e-readers. Assim, a definição de livros eletrônicos tem-se centrado mais na identificação de seu conteúdo. Gama Ramirez (2006 apud VELASCO; ODDONE, 2007, p. 3) afirma que:

\begin{abstract}
O livro eletrônico se refere a uma publicação digital não periódica, quer dizer, que se completa em um único volume ou em um número predeterminado de volumes e que pode conter textos, gráficos, imagens estáticas e em movimento, assim como sons. Também se nota que é uma obra expressa em várias mídias (multimídia: textos, sons e imagens) armazenadas em um sistema de computação. Em suma, o livro eletrônico se explica como uma coleção estruturada de bits que pode ser transportada e visualizada em diferentes dispositivos de computação.
\end{abstract}

Muitos autores afirmam que o conceito de livro eletrônico deve fazer analogia ao livro impresso. Podemos observar essa perspectiva no conceito da Enciclopédia Internacional de Ciência da Informação e 
Biblioteconomia (International Encyclopedia of Information and Library Science) do ano de 2003, que:

[...] refere-se ao livro eletrônico como o resultado da integração da estrutura clássica do livro, ou preferencialmente 0 conceito familiar de um livro, com características que podem ser fornecidas pelo ambiente eletrônico, o qual é concebido como um documento interativo que pode ser composto e lido num computador (LANDONI, 2003, p. 168, tradução nossa).

Observamos que a concepção acima restringe a leitura dos livros eletrônicos por meio do computador, mas hoje sabemos da existência de uma infinidade de dispositivos, tais como tablet, smartphones, ereades etc., que também possibilitam sua leitura, portanto o conceito pode ser ampliado para documentos interativos que possam ser compostos e lidos em quaisquer dispositivos eletrônicos, de mesa ou portáteis, que incluam uma tela.

Enfim, ao averiguar uma série de estudos, principalmente da literatura estrangeira, encontramos as autoras Vassilou e Rowley (2008), que fizeram um estudo sobre a diversidade de conceitos que apareciam na literatura e apresentaram uma definição em duas partes e em função de quatro perspectivas: meio, conteúdo/formato do arquivo, dispositivo e fornecimento. As duas partes fazem-se necessárias para capturar tanto as características persistentes de e-books, quanto sua natureza dinâmica, impulsionada em grande parte pelas diferentes tecnologias através das quais eles são disponibilizados e lidos:

(1) Um e-book é um objeto digital com conteúdo textual e/ou outro tipo de conteúdo, que deriva como um resultado da integração do conceito familiar de um livro com características que podem ser oferecidas numa ambiente eletrônico. (2) E-books possuem funcionalidades embutidas tais como funções de busca e referência cruzada, links hipertextuais, bookmarks, anotações, destaques, objetos multimídia e ferramentas interativas (VASSILOU; ROWLEY, 2008, p. 363, tradução nossa). 
A partir do entendimento do conceito de e-book em termos do conteúdo, passa-se a refletir acerca dos modelos de adoção de e-books por bibliotecas. Embora a literatura estrangeira aponte dois modelos aquele em que a biblioteca adquire e empresta dispositivos de leitura que contém livros eletrônicos como conteúdo e o modelo web-based (baseado na web) em que a biblioteca empresta apenas o conteúdo, através de transações via web-, a realidade das bibliotecas acadêmicas brasileiras é de adoção ou de análise apenas do segundo modelo, até porque os e-readers apenas recentemente chegaram ao mercado brasileiro.

Desta reflexão surgiu o questionamento: o que está acontecendo no contexto em que estamos inseridos, ou seja, que caminho e quais perspectivas estão sendo discutidas no espaço das bibliotecas do Sistema de Bibliotecas da Universidade Federal de Minas Gerais UFMG - em relação à adoção de e-books? A partir deste questionamento / problema de pesquisa, foram propostos os seguintes objetivos de pesquisa:

- Analisar os estudos de usuários de e-books empreendidos no Brasil e no exterior e suas principais descobertas;

- Investigar os estudantes de graduação da UFMG para verificar se eles estão e como estão utilizando os livros eletrônicos e os suportes para sua leitura;

- Verificar a aceitação e forma de lidar dos bibliotecários com estes livros e seus suportes.

\section{METODOLOGIA DA PESQUISA}

Não foram encontrados, na literatura, estudos de usuários de ebooks no contexto das bibliotecas brasileiras. Entre as pesquisas com usuários de e-books realizadas no exterior, ressaltam-se as de Gibbons (2001); Simon (2001); Towle (2007) e Rossi (2008).

Gibbons (2001), apresenta os resultados de uma pesquisa realizada após a experiência de 6 bibliotecas que efetuavam 0 empréstimo de e-readers contendo livros eletrônicos para seus usuários. 
O modelo de empréstimo de dispositivos de leitura, ao invés do empréstimo apenas do conteúdo não se popularizou, embora o relato de Gibbons apresente resultados positivos para a época. Temores como o de que os dispositivos se danificassem ou extraviassem não se confirmaram e a leitura através dos dispositivos foi relatada como agradável e prazerosa pelos usuários que fizeram seu empréstimo. Os maiores problemas relatados pelos bibliotecários se restringiram a questões de controle de acervo (não havia como saber especificamente o que estava sendo utilizado pelo usuário uma vez que ele tomava emprestado um conjunto grande de títulos em um único e-reader, não havia clareza se o item a ser catalogado seria cada título ou o dispositivo, entre outros) e de atualização dos títulos no dispositivo (fazer o download demandava tempo àquela época (os dispositivos faziam uso de linhas discadas).

Simon (2001) apresenta os resultados de um estudo conduzido com alunos que cursaram disciplinas por ele oferecidas tendo como material didático apenas livros eletrônicos inseridos em e-readers. Ao final da disciplina os participantes respondiam questionários anônimos sobre seus hábitos de leitura do e-book. Um total de 20 pesquisas foram completadas. O objetivo principal da pesquisa era saber quais das funcionalidades (acessar o glossário (dicionário), marcar páginas, grifar e anotar) eram consideradas importantes e eram utilizadas pelos alunos na manipulação dos e-readers e verificar a aceitação do livro didático no formato eletrônico pelos alunos.

Gemma Towle (2007) desenvolve uma pesquisa de doutorado em que estuda os impactos do livro eletrônico do ponto de vista de todos os stakeholders envolvidos na cadeia de produção e circulação do livro: autor, editoras, livrarias, bibliotecas e leitores. Além de fazer uma exaustiva revisão de literatura e das pesquisas que a antecederam, investiga, em particular, a captação e experiências de e-books nas bibliotecas públicas inglesas do ponto de vista de seus bibliotecários e dos leitores. 
Finalmente, em 2007, a Springer pesquisou bibliotecários de seis instituições para entender seus pontos de vista sobre a adoção e benefícios do e-book. Em 2008, essa editora de revistas/periódicos do setor de ciência, tecnologia e medicina deu continuidade a esse estudo com uma pesquisa de usuários finais em cinco instituições para avaliar seu uso e atitudes para com os e-books. A pesquisa revelou alguns resultados encorajadores sobre a adoção de e-books. A maioria dos usuários estava ciente da existência dos e-books e havia acessado algum pelo menos uma vez. Os entrevistados também disseram que os e-books são úteis e que gostariam de incorporá-los em suas práticas informacionais mais frequentemente. Em termos de comportamento do usuário, a pesquisa descobriu que os usuários acessam e-books principalmente para fins de pesquisa e estudo e que os tipos de e-books mais utilizados são obras de referência e livros didáticos.

A partir dessa sucinta revisão de literatura, propôs-se uma pesquisa empírica em duas etapas: uma entre os bibliotecários do sistema de bibliotecas da Universidade Federal de Minas Gerais UFMG, com coleta de dados através de entrevistas (qualitativa), e outra entre os alunos de graduação da UFMG, através da aplicação de questionários (quantitativa). Para a aplicação dos questionários e entrevistas, contou-se com a contribuição de alunos de graduação em Biblioteconomia, matriculados em uma disciplina sobre o assunto livro eletrônico. Assim, foi possível atingir uma quantidade maior de entrevistados. A coleta de dados aconteceu no período de setembro a dezembro de 2012. As entrevistas foram aplicadas presencialmente, gravadas e transcritas. Os questionários foram aplicados utilizando a plataforma do google docs, que permitiu a rápida aplicação, tabulação e análise dos dados. As seções seguintes apresentam a análise dos resultados, que subdividem-se nas duas etapas em que a pesquisa desenvolveu-se. Primeiro apresentam-se as análises resultantes das entrevistas com os bibliotecários. Na sequência, são apresentados 
gráficos e tabelas referentes aos dados colhidos entre os alunos de graduação da UFMG.

\section{RESULTADOS DA PESQUISA: ANÁLISE QUALITATIVA - O PONTO DE VISTA DOS BIBLIOTECÁRIOS}

O Sistema de Bibliotecas da UFMG é composto de um conjunto 25 bibliotecas distintas, responsáveis por prover à comunidade universitária os serviços e produtos de informação necessários ao desempenho das atividades próprias da Universidade em suas dimensões de ensino, pesquisa e extensão. A coleta de dados desta pesquisa procurou abranger todos os bibliotecários do Sistema, no entanto logrou-se realizar 17 entrevistas semi-estruturadas com bibliotecários de diferentes unidades. Os diálogos foram gravados em áudio para fins de transcrição. Realizaram-se as entrevistas com o bibliotecário-chefe ou com outro bibliotecário da unidade indicado por este. Esclareceu-se, no momento da entrevista, o conceito de livro eletrônico como uma versão digital do livro impresso (excluindo-se as publicações periódicas) que esteja disponibilizado eletronicamente para quaisquer dispositivos que incluam tela. As entrevistas envolveram questionamentos como a existência ou não de livros eletrônicos nas bibliotecas, a possibilidade de possuir uma coleção de livros eletrônicos, quais vantagens e desvantagens que os bibliotecários viam nos livros eletrônicos e se os livros eletrônicos estavam sendo considerados como uma área para possível investimento ou expansão.

Da análise das entrevistas estabeleceram-se seis categorias de análises principais que buscaram:

1. Inferir a postura dos bibliotecários em relação ao livro eletrônico, identificando-os como entusiastas, indiferentes ou se haveria alguma reação negativa;

2. Avaliar a iniciativa de compra caracterizando os bibliotecários que adquiriram livros eletrônicos de forma independente, aqueles que aguardavam determinações vindas do Sistema e 
os que não apresentaram iniciativa e não demonstraram interesse em um eventual consórcio através do Sistema.

3. Estabelecer comparações entre o livro impresso e o livro eletrônico, procurando identificar, do ponto de vista dos bibliotecários, se está havendo uma superestimação a algum formato - eletrônico ou impresso ou a provável tendência ao hibridismo.

4. Analisar a percepção dos bibliotecários sobre a necessidade de treinamento tanto da equipe técnica como a instrução aos usuários quando da inclusão dos livros eletrônicos no acervo.

5. Avaliar o grau de conhecimento dos bibliotecários em relação à compreensão dos modelos de aquisição de livros eletrônicos.

6. Conhecer a opinião dos bibliotecários sobre as vantagens e desvantagens dos livros eletrônicos, tanto na questão do formato digital como na realidade de cada biblioteca.

As duas primeiras categorias de análise propostas - postura em relação ao e-book e iniciativa de compra - dialogam bastante entre si. Buscou-se aqui inferir qual a postura dos bibliotecários diante das novas tendências lançadas pela chegada do formato eletrônico das publicações e a consequente tentativa de trazer esses conteúdos em novos suportes para dentro de cada biblioteca.

De forma geral pode-se dizer que todos os bibliotecários entrevistados reconhecem que o livro eletrônico é uma forte tendência e com a expectativa de "permanecer". E, como tal, sabem que a hora de trabalhar com o e-book vai chegar. No entanto alguns acreditam que esta é uma realidade mais distante, outros acham que já estão atrasados para a manipulação dos e-books. É o que se pode ver pelos trechos extraídos de entrevistas a seguir:

A gente tá com muita expectativa querendo trabalhar com o livro eletrônico... Vamos ver como é na Universidade.

Eu acho que a gente já tá é atrasado, né, pra adquirir os livros eletrônicos. 
Um dos entrevistados demonstra seu entusiasmo com os livros eletrônicos referindo-se às vantagens para os usuários finais. Segundo ele: "os livros eletrônicos possuem características que podem trazer grandes benefícios para os seus usuários".

Dos 17 bibliotecários entrevistados, três já efetuaram a aquisição de títulos por conta própria em suas unidades, uma bibliotecária está realizando testes para implementação de uma política de aquisição de acervo de e-books pelo Sistema de Bibliotecas e os 13 demais esperam a determinação do Sistema. Mas observa-se a divisão dos bibliotecários em duas posturas: uns aguardam que o movimento de aquisição de coleções de livros eletrônicos aconteça brevemente, mostram-se mais atentos e abertos à discussão, e cogitam mesmo a possibilidade da aquisição independente; como demonstram as falas:

Já investigamos. E já está em processo de definição dos títulos para a aquisição. Seria por conta própria. O projeto de educação a distância da faculdade está bancando o projeto.

Se Deus quiser, início do ano que vem. Porque eu nem... Se a BU não comprar... Eu vou comprar os meus raros, porque nós vamos fazer um projeto. Já conversei com o coordenador do curso. Nós vamos sentar no início de janeiro, nós vamos sentar e fazer o nosso projeto. É cinqüenta e três mil reais a base de dados, e é perpétua. É compra, mas se Deus quiser pelo menos esse a gente vai ter [...].

Atualmente nós estamos com alguma coleção disponibilizada porque foram disponibilizadas pelos editores como try-on, ou seja, livros que a gente vê a acessibilidade para a gente fazer um teste.

Outros se mostram relativamente indiferentes e distantes da discussão, pouco interessados. Os trechos abaixo apresentam exemplos destas posturas:

Não. A possibilidade de possuir uma coleção de livros eletrônicos está sendo feita pelo Sistema de Bibliotecas da UFMG. E então existe um grupo estudando, mas eu não fiz parte desse grupo no estudo inicial por falta de tempo. Na época que começou, eu estava de férias e eu não participava. Assim que tiver novas reuniões, eu pretendo participar mais ativamente por que nas primeiras reuniões 0 
outro bibliotecário [da unidade] participou, mas eu ativamente não.

Mas a gente adquirir livro eletrônico a gente não tem não (desconhece o conceito). A [nome de pessoa], né, que é a chefe da biblioteca, já tá muito empolgada querendo ver como é que é, pra gente adquirir. Mas assim até hoje, pra que a gente possa ter uma atitude pra comprar, a gente ainda não. Entrevistadora: mas vocês chegaram a pesquisar preço? Não, eu pelo menos nunca fiz [...]

Não. [...] Porque não possui demanda para tanto, os alunos não têm interesse. A biblioteca é só de pós-graduação, os outros alunos utilizam a Biblioteca Central.

A terceira categoria da análise foi a comparação que os bibliotecários fizeram do livro impresso com o livro eletrônico. Subdividimos essa categoria em três subcategorias, em que identificamos os bibliotecários que superestimam o livro impresso, aqueles que superestimam o livro eletrônico e outros que tendem ao hibridismo, ou seja, a utilização tanto do livro impresso quanto do eletrônico.

$\mathrm{Na}$ análise das entrevistas percebemos que alguns bibliotecários não se sentem à vontade realizando a leitura do livro eletrônico, levando-nos a crer sua superestima pelo livro impresso, assim como podemos observar nas seguintes declarações:

Eu praticamente não gosto muito não, eu acho que depende no caso, igual o livro, se eu pegar um livro, uma literatura, por exemplo, eu prefiro pegar o livro e ler a pegar na tela e ler.

As mudanças já são visíveis, mas não muda o sabor de uma boa leitura no livro impresso em que você toca e folheia as páginas, volta ao ponto que quiser sem ter que usar uma tela iluminada. Não troco este prazer de uma boa leitura em livro impresso por um eletrônico.

Observou-se que, em alguns casos, aqueles que declararam não ter interesse pelo livro eletrônico, são profissionais que já estão próximos da aposentadoria e acreditam que esse legado ficará para os futuros profissionais que irão ocupar suas posições no sistema. 
Por outro lado, da mesma forma que foram poucos os bibliotecários que fizeram parte do grupo que superestima o livro impresso, também não foi grande o grupo daqueles que superestimam o livro eletrônico. Em algumas falas, nota-se que o profissional é otimista no que diz respeito à tecnologia do livro eletrônico:

Já faz parte do presente e no futuro vai... com certeza. Todos os eventos que a gente participa na... da minha área de biblioteconomia e ciência da informação, sempre fala...é muito mais prático, não tem esse problema de espaço e o mundo já esta acostumado com a tecnologia.

O ensino a distância é outro aspecto importante ressaltado por um entrevistado e que cada vez mais está recebendo investimento, tanto das instituições públicas quanto particulares. Os livros eletrônicos têm sido grandes aliados nessa forma de ensino que está em crescimento e que possibilita a inclusão de uma diversidade de estudantes, como aqueles que possuem alguma dificuldade de se locomover. Nota-se a preocupação do entrevistado nas palavras que se seguem:

Acho que, principalmente para nós que trabalhamos muito com educação a distância, esta é uma questão fundamental. Acho que vai pegar, não tem jeito, em algumas áreas mais rápido e em outras mais lento.

A maioria dos entrevistados apresentou uma tendência ao hibridismo. Alguns estão vivenciando esse momento e até chegam a oferecer simultaneamente o acesso ao mesmo título em ambos os formatos, eletrônico e impresso. Outros demonstram pretender oferecer essa opção aos seus usuários em breve. Isso confirma-se no exposto por três entrevistados:

Adquirimos esses todos, os 41, nós temos exemplar impresso aqui na biblioteca e o acesso online, temos os dois.

Um comentário pessoal, é que eu prefiro o livro em papel, não tenho nada contra, acho que novo tem que chegar, tem 
que vir, e tem que ser bem aproveitado tanto por nós bibliotecários, como pelos usuários em geral. Mas eu acho que a Universidade precisa entrar nessa época, acho que já até passou um pouco, mas vai entrar pelo que estou sabendo provavelmente ano que vem. E é serem bem aproveitados, e os usuários também darem sugestões de títulos que possam ser adquiridos, e usarem também a nossa coleção física, até que o momento... acho que durante muito tempo vai ficar híbrido. $E$ depois acho que deve converter uma parte, principalmente essas exatas, sociais para essa parte digital. Mas o livro físico eu acho que não acaba não.

Eu acho assim que o livro em papel não acaba, mas o livro eletrônico parece que vai pegar e parece que vai ficar... eu acho que vão caminhar paralelos.

Os bibliotecários são quase unânimes ao apontar a forte tendência ao hibridismo. O fim do livro de papel foi uma possibilidade praticamente descartada ao passo que a tendência do e-book se consolidar é forte; fato que indica a convivência dos dois modelos. Como aponta um dos entrevistados "de um modo geral o que as pessoas querem é o acesso" à informação, independentemente de em qual suporte.

A categoria que avalia a percepção da necessidade de treinamento foi subdividida em três subcategorias. Dos 17 bibliotecários entrevistados, 13 percebem a necessidade de treinamento, dois bibliotecários oscilam entre a indiferença e a crença de que já estão preparados e dois bibliotecários não responderam.

Os que crêem precisar de treinamento apresentam, por exemplo, dúvidas relativas ao processamento técnico: Como emprestar e como controlar? Como atender ao usuário?

Sim, acho que é começando do básico, porque a gente nunca trabalhou. Nem todos nós trabalhamos com livro eletrônico, apesar de que no nosso dia-a-dia acredito que todos nós já tenhamos acessado, mas a gente vai precisar de um treinamento para saber os detalhes, como que é feito esse acesso, a pesquisa para encontrar o livro vai ser diferente, vai ser uma base de dados separado do catálogo do Pergamum. Então é esse tipo de treinamento para poder oferecer ao usuário esse acesso e facilitar a vida dele. Assim como a gente tem treinamento para o livro físico, para 
localizar, para organizar e tudo, teria que ter um treinamento direcionado e especifico para o meio digital.

Todo mundo. O pessoal de processamento técnico, referência, formação e desenvolvimento de coleção precisam de treinamento. Noção nós temos por participarmos de congressos, palestras etc.

Ah com certeza. É uma coisa nova e... Tem que ter treinamento para atender o usuário. Eu acho que é... O treinamento deve ser do básico. De só viver na prática como é que é esse empréstimo, como que vai ser a devolução. $O$ processo todo. Tem que passar por tudo do início ao fim. Tanto os servidores efetivos quanto os estagiários que tiverem trabalhando, né? No local. É de informática e do funcionamento, né? Como é que funciona o empréstimo. Por mais difícil que seja. Tem que mostrar para todo mundo, passo a passo.

Houve aqueles que, se num primeiro momento afirmaram não haver necessidade de treinamento, após refletirem melhor consideraram, ao menos, a necessidade de adaptação. Extratos de uma mesma entrevista demonstram essa situação:

Não, porque na verdade todos nós somos bem capacitados pra tecnologia, todo mundo sabe fazer pesquisa na internet. Todo mundo sabe baixar, todo mundo sabe fazer download, então é... É aprender a vivenciar isso, deixar de ter o físico pra ter o imaterial, né, é mais, é bem tranquilo. [...]. Acho que eles precisam ser trabalhados, eles precisam ser indexados como o livro impresso. Então eu acho que não é só adquirir, não é só ter... não adianta você comprar uma montanha de coisas sem ser trabalhada, né? Como é que você vai recuperar aquilo? Só autor e título a gente sabe que não é suficiente, né! [...] Não sei o que é que vai exigir, mas eu acredito que não... eu acho que vai ser como livro impresso, uma vez localizado o usuário mesmo que vai baixar aquilo que é do seu interesse... num sei... pode ser... num dá pra saber não... mas pode ser que tenha se a gente quiser trabalhar internamente, jogando na base Pergamun, fazendo indexação talvez a gente tenha que saber se vai ter um modo de fazer isso. Mas depois a gente vai ajeitando, adaptando e com certeza fica mais fácil".

A questão do modelo de aquisição é, talvez, aquela menos clara para os bibliotecários, e também o grande entrave para que o Sistema de Bibliotecas da UFMG não possua, até o presente momento, uma coleção expressiva de livros eletrônicos. O mercado vem oferecendo 
alternativas de aquisição nada atrativas para as bibliotecas, em que a aquisição é feita em "pacotes", que incluem uma coleção com alguns títulos de grande interesse das bibliotecas, e outros tantos de menor ou nenhum interesse. Parece ser necessário que a instituição se articule politicamente para que ela (instituição de ensino) apresente uma proposta de aquisição para as editoras que contemple sua necessidade, ao invés de analisar as propostas fechadas apresentadas pelas próprias editoras.

Das entrevistas feitas, 10 bibliotecários afirmaram conhecer as alternativas mercadológicas de aquisição. Dois afirmaram conhecê-las mas, indagados acerca das diferenças entre uma e outra, demonstraram confusão. Um bibliotecário não respondeu a essa questão e os demais não fazem sequer ideia das opções de mercado.

Um dos aspectos discutidos foi o da quantidade de empréstimos simultâneos (número limitado versus quantidade ilimitada). Mesmo sabendo que para uma quantidade ilimitada de acessos a um mesmo título os valores de aquisição são superiores, esse é indubitavelmente o modelo preferido pelos bibliotecários:

Esse modelo permite que maior número de usuários tenha acesso simultâneo a um título específico, o que favorece a disseminação da informação e elimina as listas de reservas criadas no sistema da biblioteca.

No entanto, houve bibliotecário que preferisse a aquisição do modelo "um usuário por título", justificando-se que, durante a implantação do acervo de livros eletrônicos, deve-se adaptar paulatinamente ao processo: 
Um usuário por título. Nessa transição a gente tem que buscar o mais próximo do formato físico. Vamos com os pés no chão. Disponibilizá-los no [sistema] Minha UFMG'.

Um segundo aspecto refere-se à confrontação de modelos de aquisição versus modelos de assinatura (em geral anuais). Se os primeiros apresentam a vantagem de que uma vez adquiridos os títulos, a biblioteca torna-se "dona" deles, por outro lado o armazenamento digital dos conteúdos (e, portanto, a garantia de espaço nos servidores, de existência de servidores online 24 horas, de integridade física dos arquivos, etc.) passa a ser de responsabilidade da biblioteca. No modelo assinado, vende-se o acesso, e a responsabilidade de armazenamento e manutenção é da editora. Há, no entanto, que arcar-se com custos de renovação da assinatura a cada vez que ela vence.

Eu prefiro a aquisição dos livros e não a liberação de acessos, para não correr o risco de não ter mais acesso aos livros por rompimento da assinatura.

Eu não sei o nome do modelo da assinatura, mas eu já assisti algumas apresentações que tem o modelo de assinatura e tem o modelo de aquisições. $A$ assinatura você assina aquela base de e-books durante um determinado período, por exemplo, um ano. Você paga lá e seus usuários têm acesso durante um ano. E a compra é como se fosse a compra de um livro físico. Você compra e o acesso é seu, é perpétuo. Então acho que prefiro a compra.

Finalmente, buscou-se avaliar quais as vantagens e desvantagens percebidas pelos bibliotecários em relação à incorporação de livros eletrônicos ao acervo de suas bibliotecas. Quando indagados sobre as vantagens de se usar os livros eletrônicos, a maioria dos bibliotecários considerou o acesso rápido e remoto para o maior número de usuários como a principal vantagem de se usar e-books:

\footnotetext{
1 Portal com versões personalizadas para professores, alunos e funcionários da UFMG, o MinhaUFMG proporciona integração de toda a comunidade universitária em um único espaço virtual.
} 
A vantagem é, além do acesso, que o livro tá disponibilizado 24 horas, é mais pessoas poderem usar o livro ao mesmo tempo.

As vantagens, acho que o acesso remoto é uma vantagem bem evidente. E a possibilidade de você ter um conteúdo mais dinâmico.

O relato acima, além de ressaltar a questão do acesso remoto, remete ao conteúdo dinâmico, propiciado pelo caráter multimídia do livro eletrônico. Embora essa vantagem não tenha figurado entre as principais e mais citadas pelos bibliotecários, é bastante interessante a referência a ela.

Também se encontrou um considerável número de bibliotecários que elencaram a economia de espaço físico como uma grande vantagem de se usar os livros eletrônicos:

A questão de espaço físico, porque o acervo cresce, mas e o espaço continua o mesmo, ou até diminui, dependendo do caso, né?

Em relação às desvantagens, a maioria dos entrevistados relatou o desconforto da leitura na tela dos dispositivos, devido ao excesso de luz emitida, e considerou o processo de leitura lento e cansativo:

A desvantagem pode ser o que ainda não, mas eu não acredito que seja alguma coisa que vá permanecer durante muito tempo. Eu acho que ainda não é tão confortável a leitura de textos muito longos, principalmente de textos literários.

Além disso, lembraram-se do preço dos dispositivos, considerado muito caro, somado com a obsolescência dos equipamentos em um curto espaço de tempo. 


\section{RESULTADOS DA PESQUISA: ANÁLISE QUANTITATIVA - O PONTO DE VISTA DOS USUÁRIOS}

Em paralelo com a pesquisa que investigava o olhar dos bibliotecários, buscou-se ver como os alunos de graduação da UFMG, usuários finais de um possível acervo de livros eletrônicos, faziam uso dos livros eletrônicos ou, caso não fizessem, que expectativas teriam a seu respeito.

Em 2012 a UFMG oferecia 66 diferentes cursos de graduação, divididos em sete áreas do conhecimento, a saber: Agrárias; Engenharias; Exatas e da Terra; Humanas, Linguística, Letras e Artes; Saúde e Sociais Aplicadas. Foi aplicado um total de 1531 questionários, distribuídos entre seis dessas áreas, conforme ilustrado conhecimento

Gráfico 1 - Total de respondentes por área do

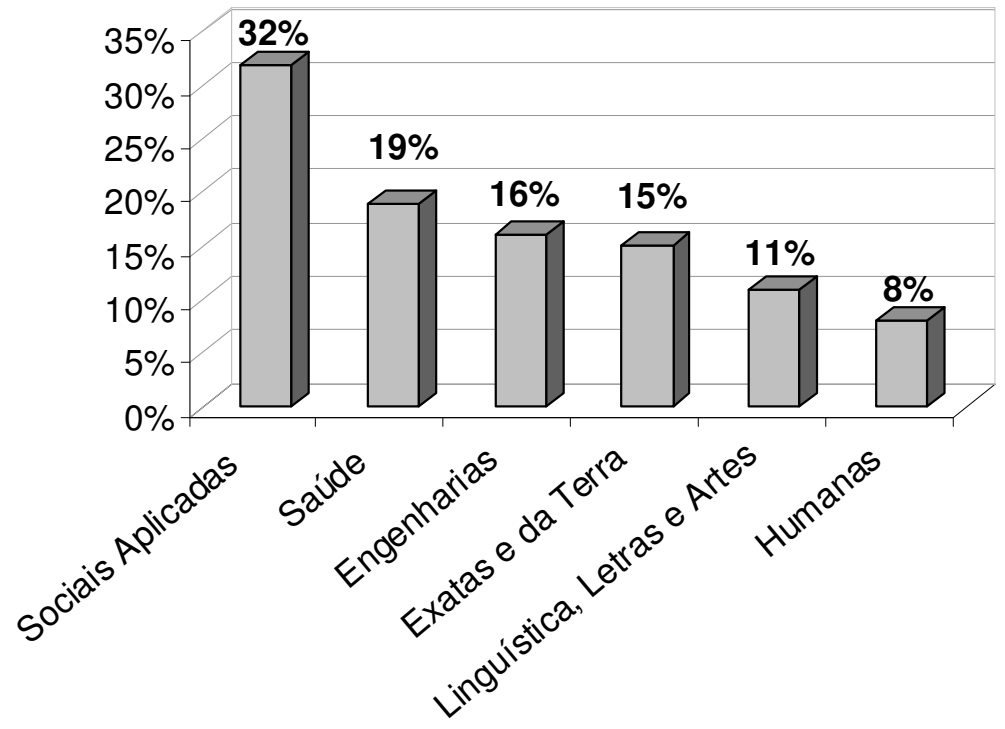

Fonte: Dados da pesquisa coletados em set-dez/2012

Tinha-se a preocupação de se verificar se estes usuários realmente estão utilizando o Sistema de Bibliotecas da UFMG para suprir suas necessidades bibliográficas. Nota-se no gráfico 2 , que a maioria, $78 \%$ dos entrevistados, continua utilizando a biblioteca da 
UFMG para ter acesso aos livros. Observa-se que o total de resposta é maior que $100 \%$, isso acontece porque os entrevistados podiam escolher mais de uma opção de resposta. $68 \%$ dos entrevistados fazem compra da literatura utilizada e $54 \%$ utilizam serviço de fotocópia, isso retrata um relativo poder aquisitivo do grupo de alunos da UFMG. $47 \%$ dos entrevistados afirmam fazer outros tipos de empréstimos, ou seja, empréstimos em outras bibliotecas que não do sistema UFMG, ou entre familiares, colegas ou amigos.

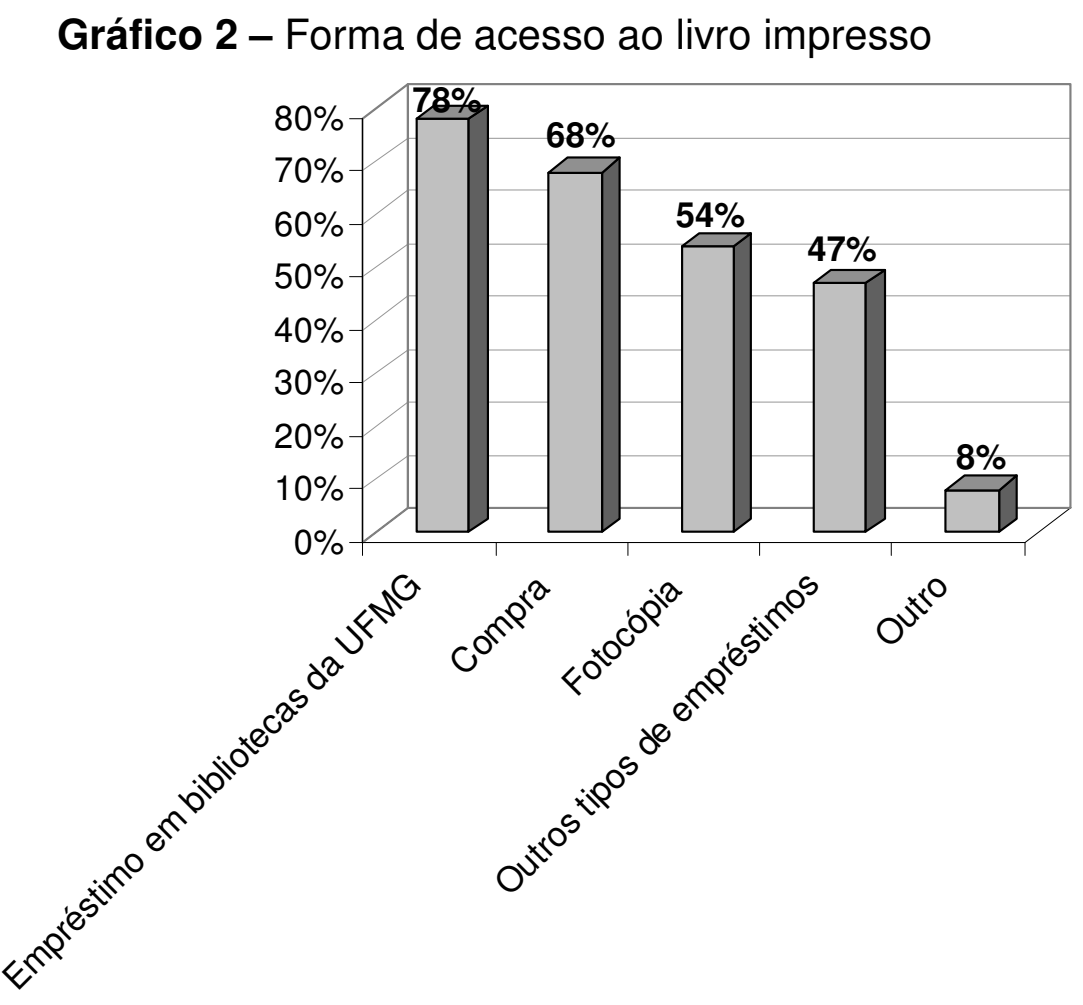

Fonte: Dados da pesquisa coletados em set-dez/2012

Buscou-se analisar, através da pesquisa, se os alunos de graduação da UFMG possuem familiaridade com as novas tecnologias, em especial, o computador. Obteve-se os dados de que somente $2 \%$ lidam há menos de um ano com o computador e que quase a metade, um percentual de $49 \%$, utilizam o computador de seis a dez anos. Além disso, o percentual de $35 \%$ de alunos, que declararam utilizar o computador acima de dez anos, permite inferir que apesar de existir um 
número considerável de alunos que possuem dificuldade com as tecnologias, aqueles que lidam sem dificuldades com elas, se sobressaem (Grafico 3).

Gráfico 3 - Tempo de uso do computador

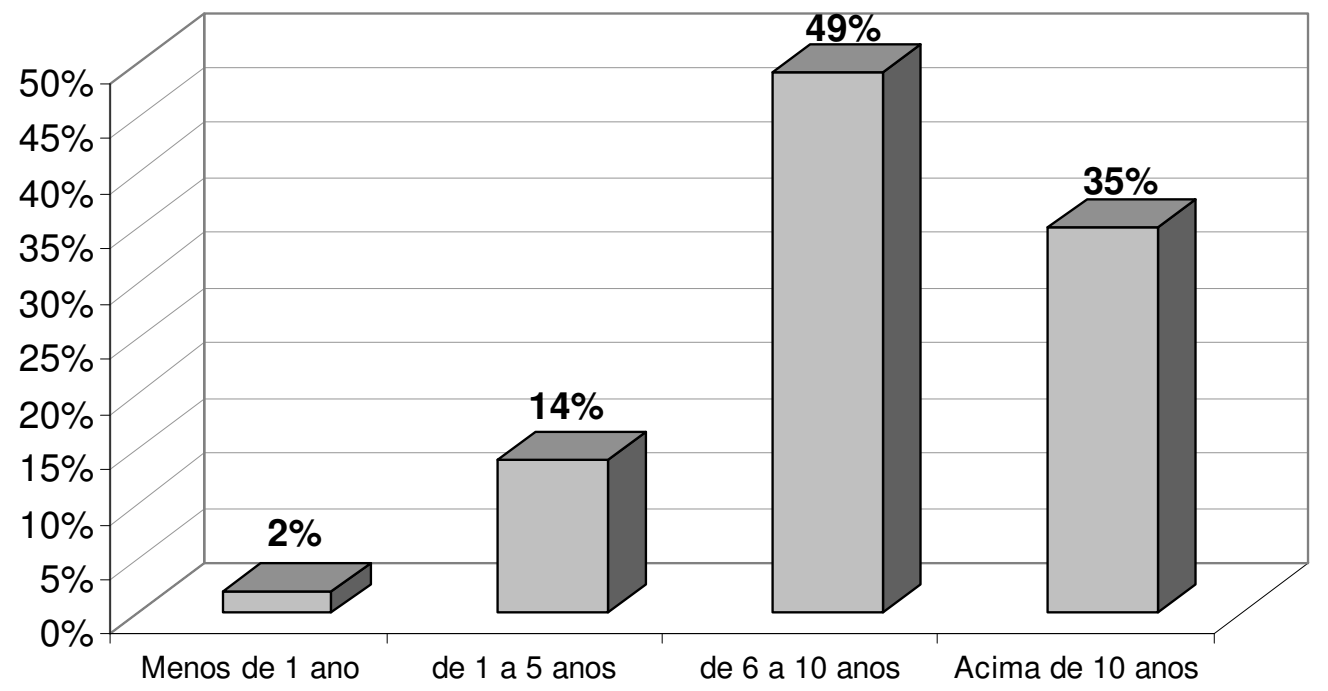

Fonte: Dados da pesquisa coletados em set-dez/2012

Assim como a maioria dos bibliotecários entrevistados do Sistema de Bibliotecas da UFMG declarou, o acesso é uma das principais vantagens do livro eletrônico. Entretanto, para que esse acesso seja real, a internet se faz necessária. Dessa forma, a pergunta "onde você acessa a internet" demonstrou que $86 \%$ dos entrevistados possuem internet em casa, fator que facilita o processo de empréstimo ou até mesmo aquisição dos livros eletrônicos. Quase todos os entrevistados possuem acesso à internet em mais de um local, tendo assinalado mais de uma opção no questionário. Chamou atenção, entre as respostas dadas na opção outros, o acesso à internet móvel. 
Gráfico 4 - Local de acesso à Internet

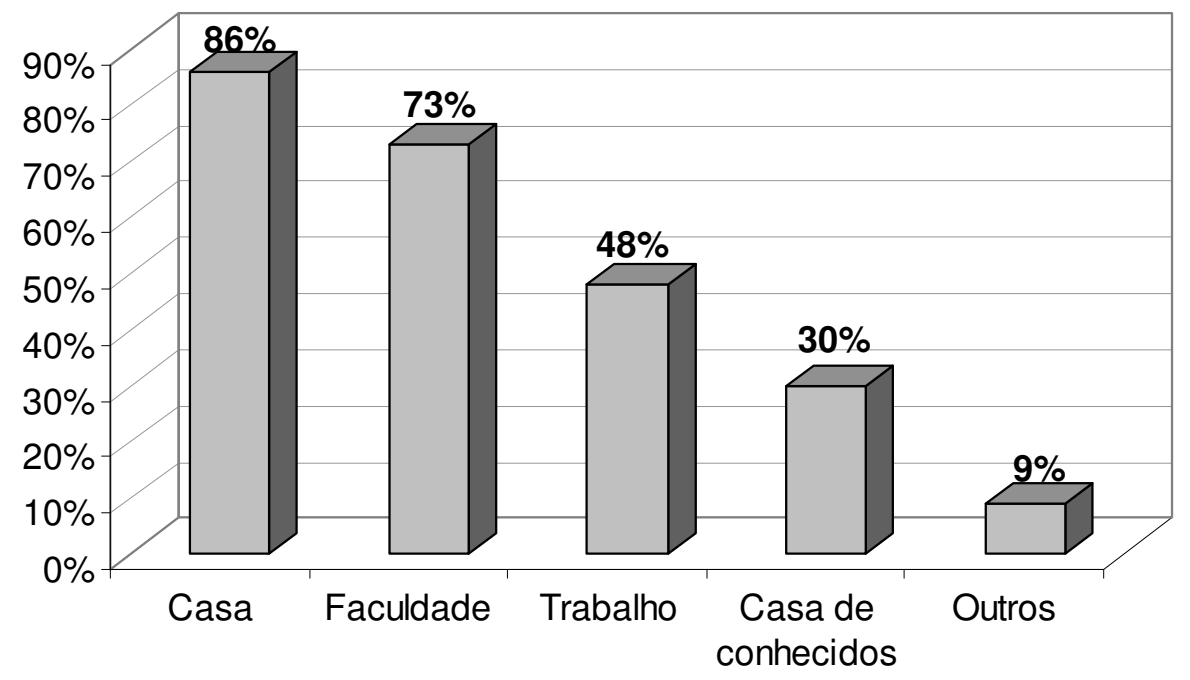

Fonte: Dados da pesquisa coletados em set-dez/2012

É importante ressaltar que foi levantada a possibilidade de muitos alunos não saberem com clareza o que era um livro eletrônico. Assim, prevendo essa problemática e buscando chegar o mais próximo de respostas verdadeiras, além da explicação da pesquisa no início do questionário, inseriu-se novamente o conceito de livro eletrônico antes de o aluno responder se já havia utilizado ou não. Foi ressaltado que o conceito de livro eletrônico estava relacionado ao conteúdo e não ao dispositivo de leitura, e que um livro eletrônico não deveria ser confundido com um artigo ou texto menor. 880 respondentes (58\%) afirmaram já terem utilizado um livro eletrônico, mas 651 (42\%) disseram que nunca utilizaram um. 
Gráfico 5 - Leitores que já fizeram uso de livro eletrônico

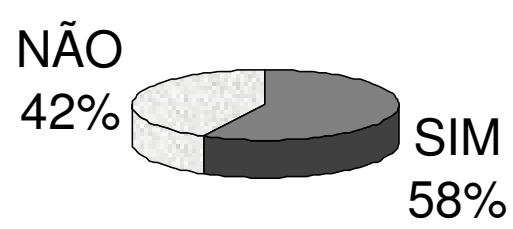

Fonte: Dados da pesquisa coletados em set-dez/2012

A análise desse dado foi feita separadamente por área do conhecimento e percebeu-se que os alunos de Linguística, Letras e Artes e os alunos de Humanas estão mais familiarizados com a leitura do livro eletrônico, ao passo que os alunos das áreas de Saúde e Sociais Aplicadas são os que menos utilizam o livro nesse suporte, conforme pode ser visto no grafico 6.

Gráfico 6 - Uso de livro eletrônico por área do conhecimento

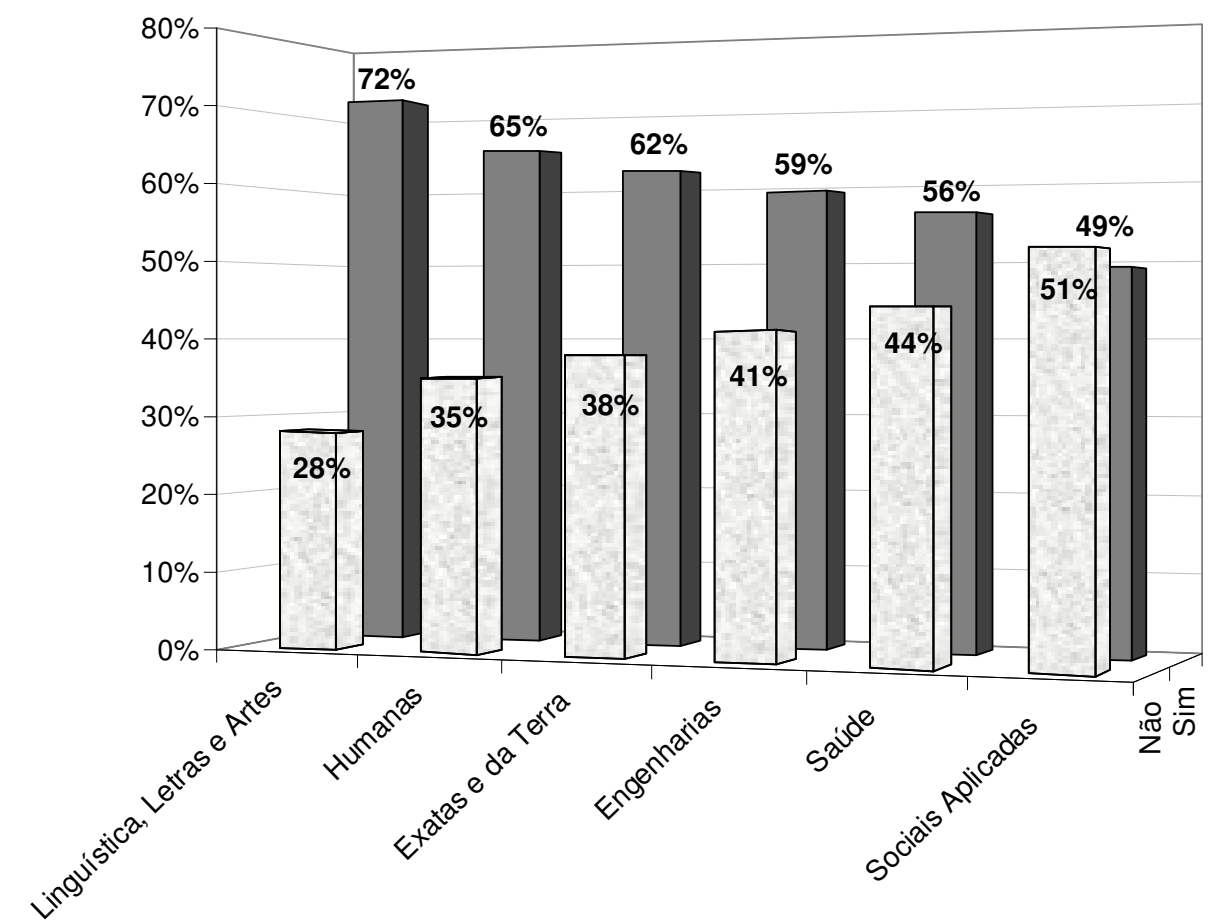

Fonte: Dados da pesquisa coletados em set-dez/2012. 
Entre os dispositivos para realizar a leitura do livro eletrônico, os 880 entrevistados disseram utilizar mais o computador de mesa, correspondendo a um percentual de $43 \%$. Somente $9 \%$ afirmaram utilizar algum e-reader, ou seja, um leitor específico para livro eletrônico, como o kindle ou kobo, por exemplo. Muitos entrevistados utilizam mais de um dispositivo para fazer a leitura do livro eletrônico, por exemplo desktop e notebook ou notebook e tablet.

Gráfico 7 - Dispositivo empregado para leitura do livro eletrônico
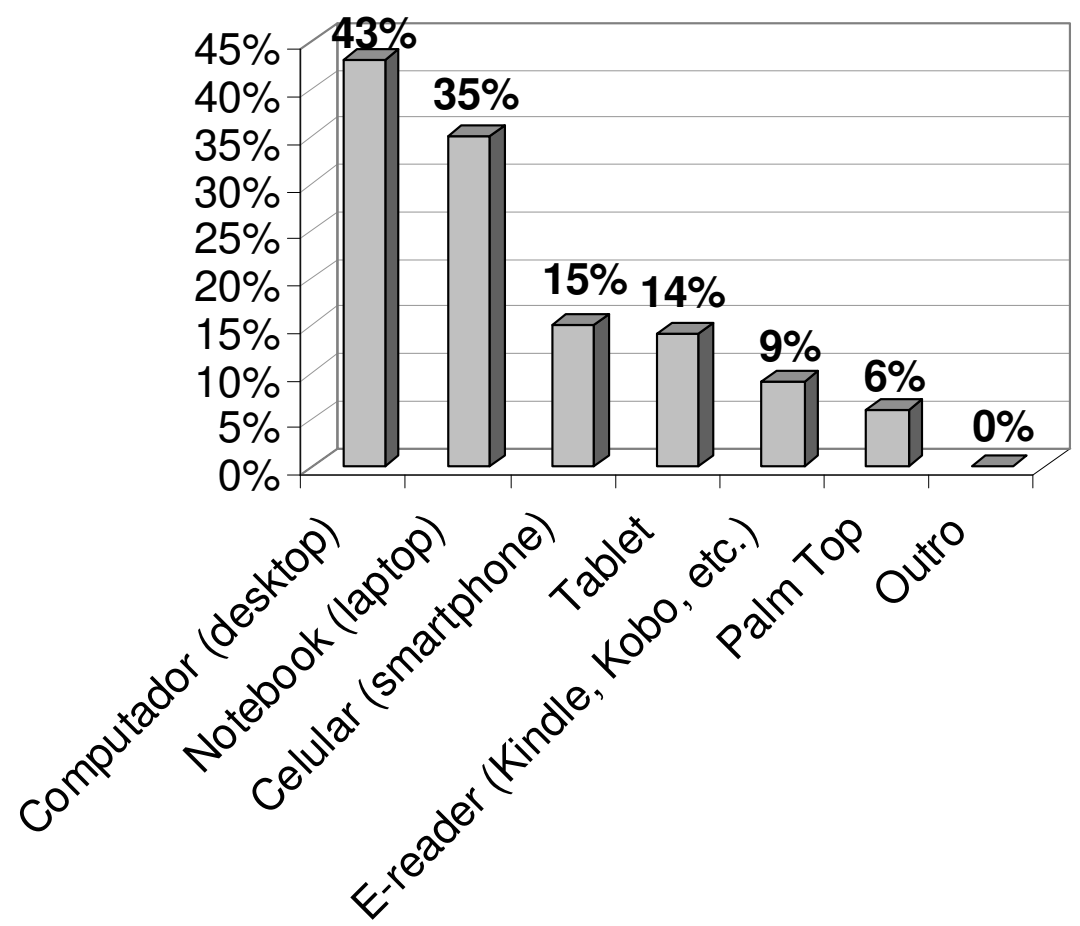

Fonte: Dados da pesquisa coletados em set-dez/2012.

A pergunta sobre a forma em que entrevistados tinham acesso aos títulos dos livros eletrônicos gerou 1448 respostas diferentes entre os 880 usuários dos livros eletrônicos que responderam essa questão (eles podiam acessar o livro eletrônico de diferentes formas). 754 (86\%) dos alunos de graduação da UFMG que foram entrevistados e usam o livro eletrônico, afirmaram fazer o download gratuito, 254 (29\%) compram os títulos, 198 (22,5\%) buscam em outras bibliotecas ou fazem empréstimos com conhecidos, 167 (19\%) fazem empréstimos em 
Bibliotecas da UFMG e 95 (11\%) marcaram a opção outros. Entre os que responderam outros, um número muito significante de respondentes assumiu fazer o download pirata (Grafico 8).

Gráfico 8 - Forma de acesso aos títulos

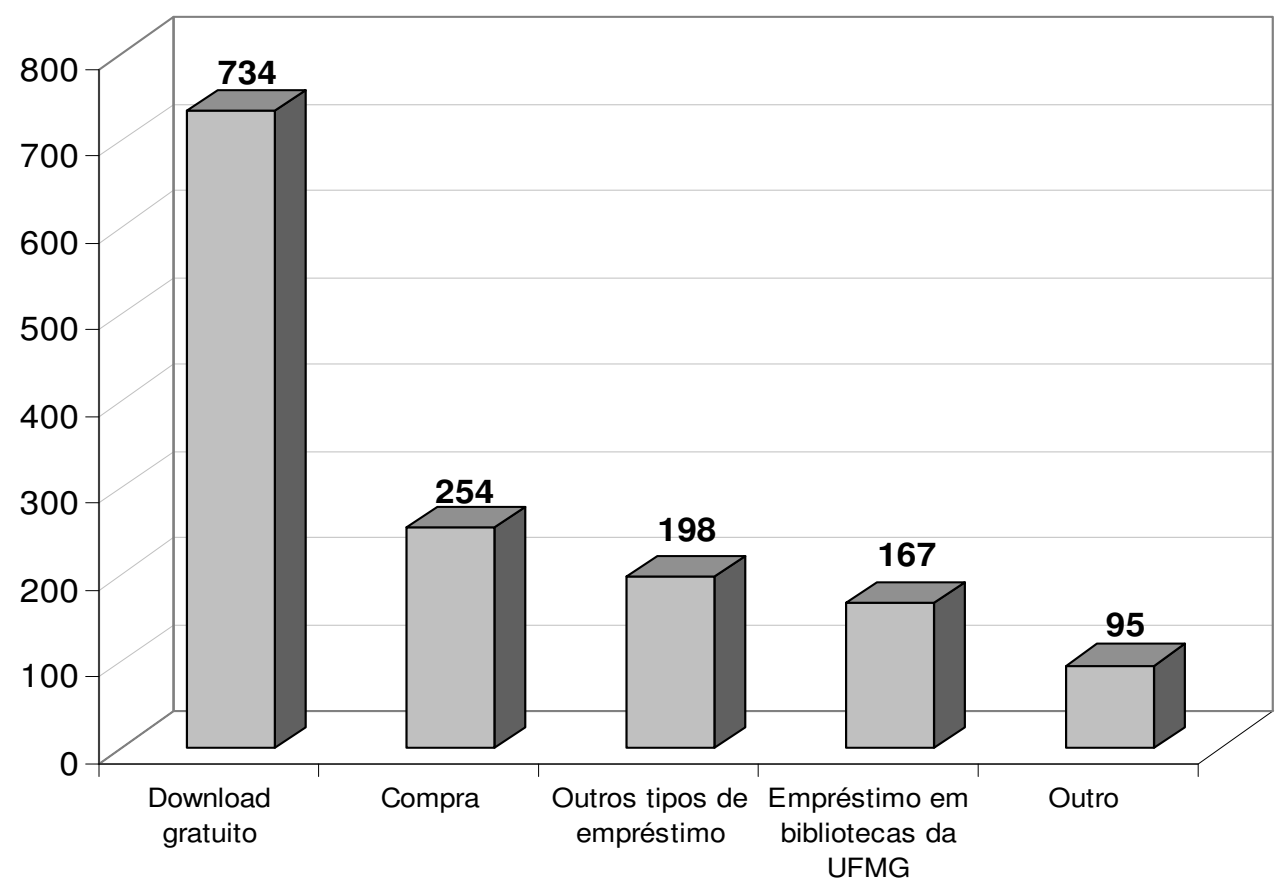

Fonte: Dados da pesquisa coletados em set-dez/2012.

Apesar de se ter a preocupação de criar um questionário em que as perguntas fossem objetivas e claras, percebe-se uma incoerência nos $11 \%$ dos entrevistados que declararam fazer empréstimo nas Bibliotecas da UFMG, já que apesar de haver alguns poucos livros adquiridos em uma ou outra biblioteca do sistema, até a data de realização da pesquisa quantitativa com os bibliotecários do sistema, anteriormente citada, os e-books adquiridos por essas bibliotecas não eram divulgados para a comunidade acadêmica da UFMG como constantes no acervo. Portanto, a única possibilidade de acesso a livros eletrônicos através do Sistema de Bibliotecas da UFMG seria via Portal de Periódicos CAPES, um serviço oferecido pelas Bibliotecas.

Entre os 880 respondentes que já utilizaram o livro eletrônico, buscou-se averiguar quais as funcionalidades, entre as citadas na 
literatura, eles mais utilizam. Essas funcionalidades incluem acessar dicionário ou glossário diretamente a partir de um clique em palavra contida no próprio livro, fazer anotações no próprio livro, sublinhar, marcar páginas, alterar o tamanho da fonte. $O$ gráfico 9 apresenta os resultados apontados pelos entrevistados.

\section{Gráfico 9 - Funcionalidades do livro eletrônico utilizadas pelos entrevistados}

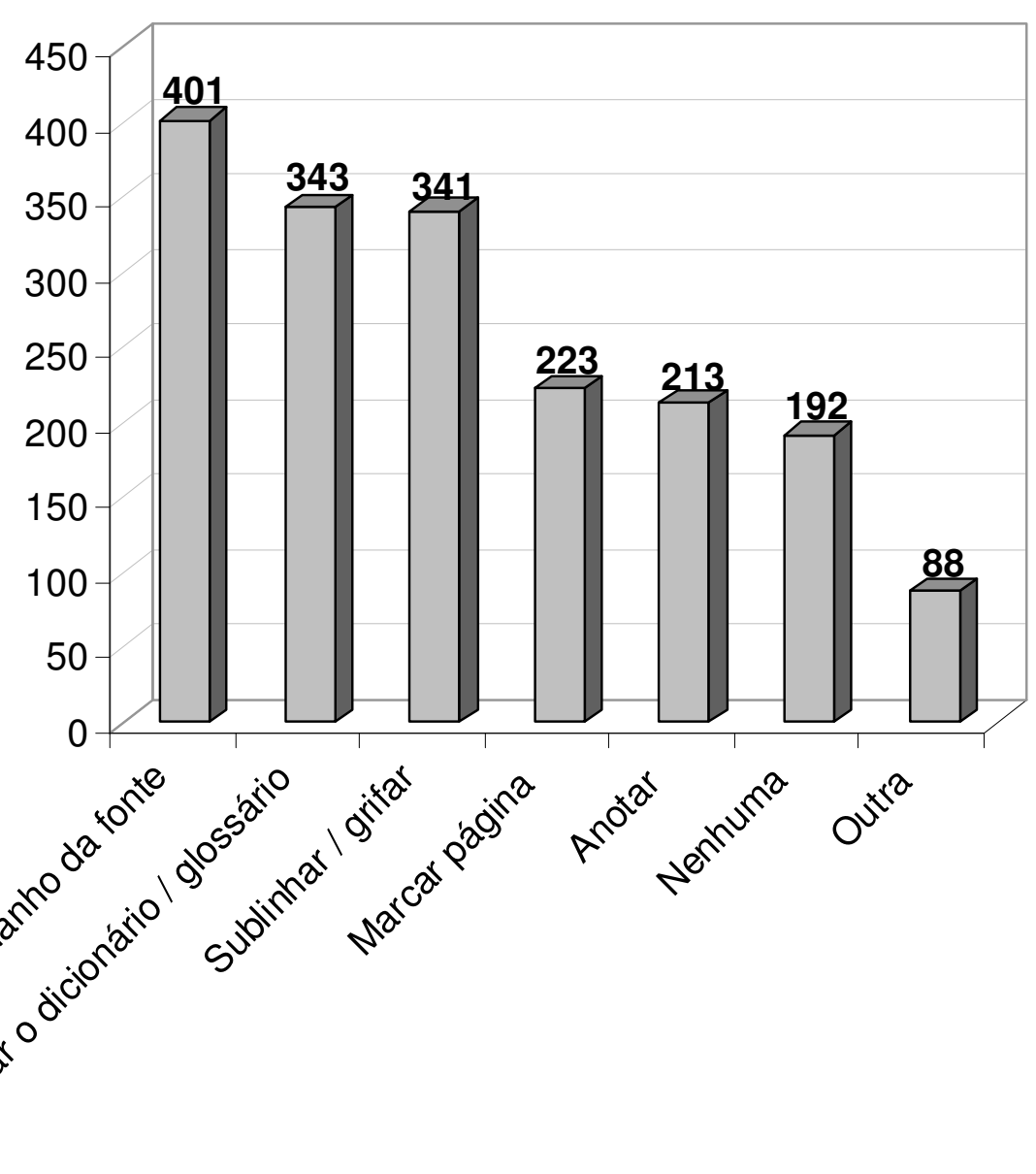

Fonte: Dados da pesquisa coletados em set-dez/2012.

O formato de arquivo mais utilizado para leitura de livro eletrônico pelos alunos de graduação da UFMG é o PDF, citado por $93 \%$ dos 880 entrevistados que usam livro eletrônico, como apresentado no gráfico 10. Percebe-se através desse quantitativo que a maioria dos entrevistados pode ter dificuldades em ler seus livros em um e-reader, já 
que o texto em PDF, em alguns leitores como o kindle, fica com uma formatação não agradável aos olhos do leitor. Fica, ainda, em suspenso a questão de que um arquivo em PDF nem sempre configura um livro eletrônico, pois nem sempre possui características que permitem a recuperação/pesquisa do conteúdo textual. Um arquivo digitalizado nem sempre é um livro eletrônico (discussão essa que está no cerne da definição/conceituação de livro eletrônico). Por outro lado, observa-se que os livros no formato ePUB foram citados por apenas $10 \%$ dos leitores (85 entrevistados entre os 880 que usam livros eletrônicos), sendo esse o formato mais popularizado, atualmente, entre os e-books. E, ainda, que o formato azw, proprietário da Amazon, lido pelo e-reader kindle, foi citado por apenas $2 \%$ da amostra, ou seja por 19 respondentes entre os 880 entrevistados que usam livros eletrônicos.

Gráfico 10 - Formatos de arquivo para leitura de livro eletrônico utilizados pelos entrevistados

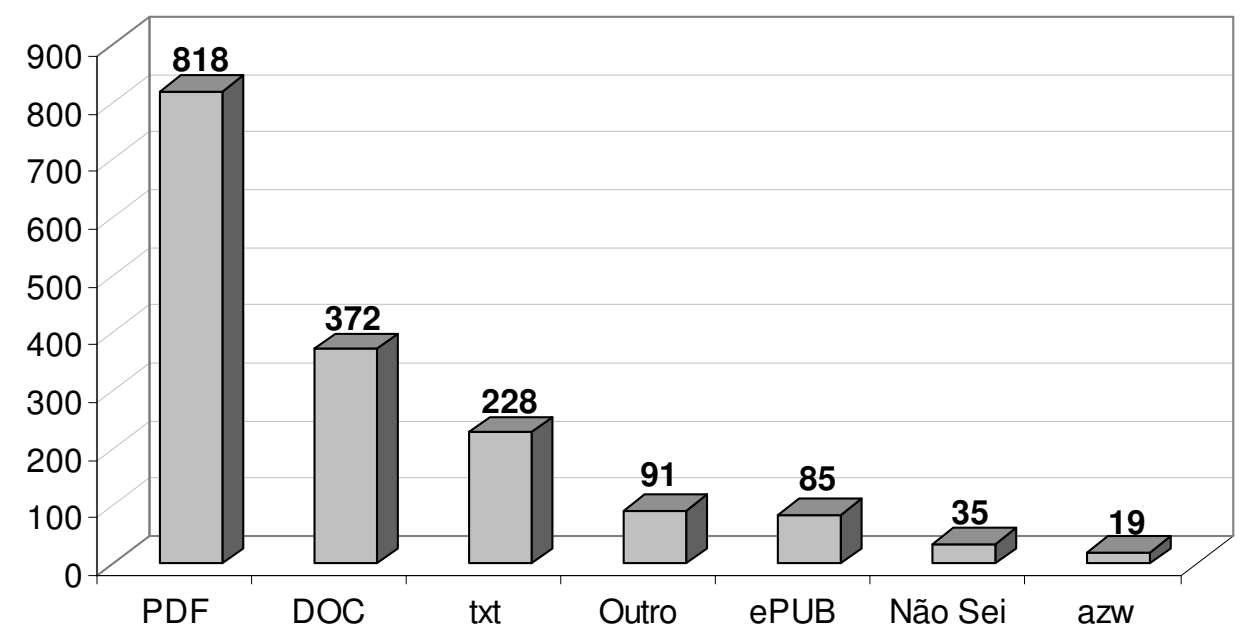

Fonte: Dados da pesquisa coletados em set-dez/2012.

Assim como algumas pesquisas já realizadas no exterior mostram, a maior parte dos alunos entrevistados também utiliza o livro eletrônico para atividades acadêmicas, pesquisas estudos. Dos 880 usuários de livros eletrônicos, 625 , ou seja, $71 \%$, relataram usar o livro eletrônico para essa finalidade. Somente $26 \%$ disseram fazer uso dos 
livros eletrônicos para o lazer, com a leitura de obras literárias, autoajuda etc. Pode-se inferir que na pesquisa acadêmica o usuário lê fragmentos de uma obra e nem sempre a obra completa, e que se beneficia de ferramentas de pesquisa por palavra-chave, por assunto etc., o que facilitaria a escolha pelo livro eletrônico nesse tipo de atividade.

Gráfico 11 - Finalidade do uso do livro eletrônico Lazer (leitura literária, auto-ajuda, etc.) $233(26 \%)$ outro $22(3 \%)$

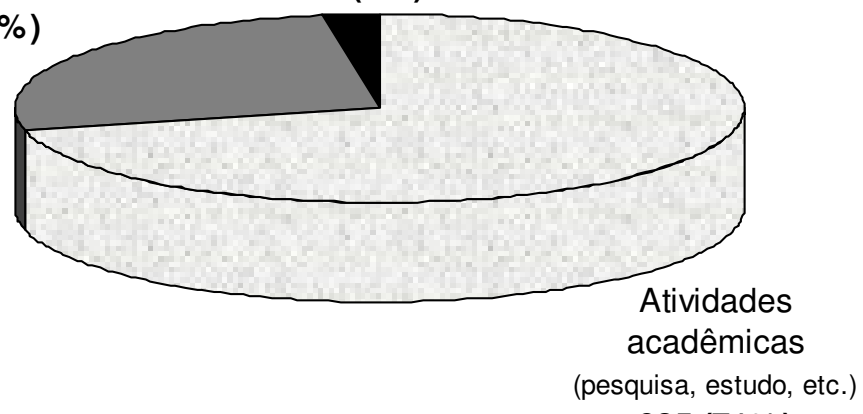

$625(71 \%)$

Fonte: Dados da pesquisa coletados em set-dez/2012.

Aos 651 entrevistados que afirmaram não utilizarem o livro eletrônico, perguntou-se qual ou quais eram os motivos por essa escolha: $41 \%$ (266 entrevistados) disseram ter desinteresse nesse formato de livro, 40\% (257) desconhecem, $24 \%$ (156) responderam que o preço seria o motivo, $21 \%$ responderam ser outro tipo de motivo e 12 $\%$ assumiram terem dificuldades com novas tecnologias, conforme apresentado no gráfico 12 . 
Gráfico 12 - Motivo pelo não uso do livro eletrônico

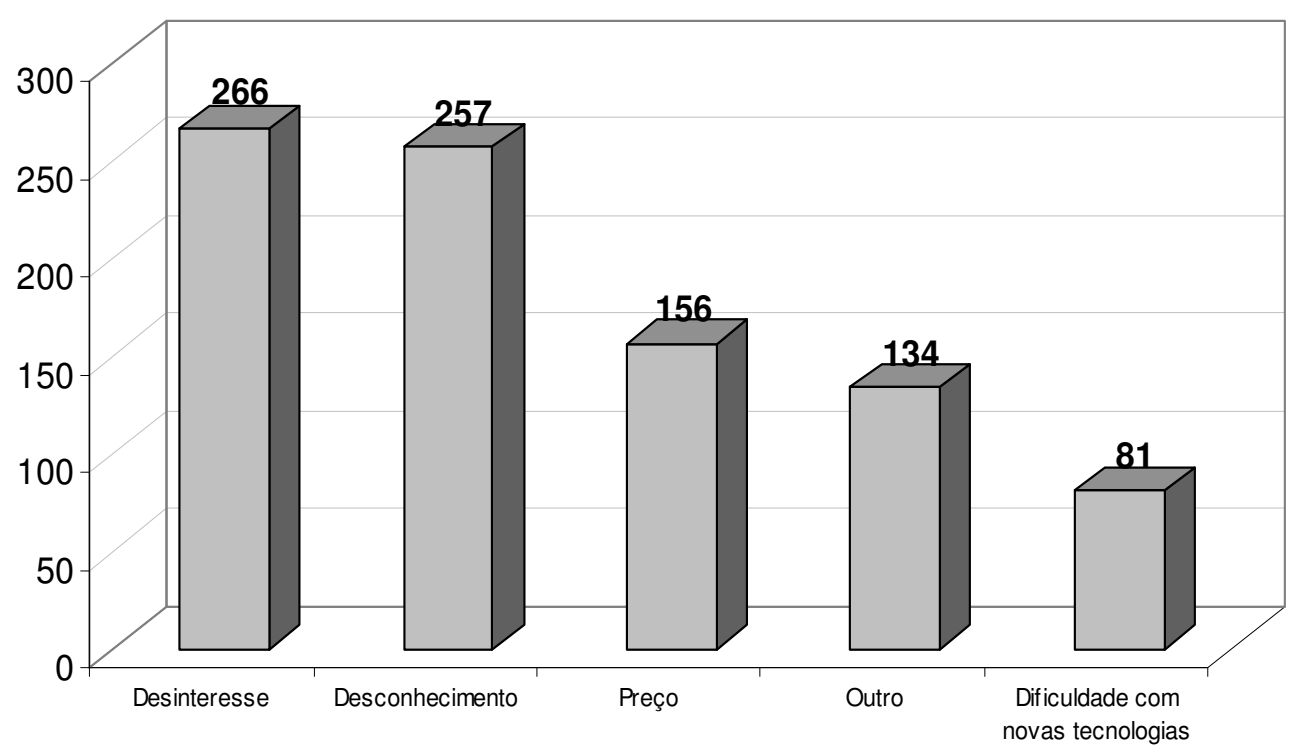

Fonte: Dados da pesquisa coletados em set-dez/2012.

Dentre os $21 \%$ (134) entrevistados que responderam não usar por outros motivos além dos elencados no questionário, muitos disseram não se sentirem confortáveis na leitura de um livro eletrônico, sentirem cansaço nos olhos e terem o prazer da leitura no livro impresso.

\section{CONSIDERAÇÕES FINAIS}

De forma geral conclui-se que todos os bibliotecários apresentam opiniões bem claras a respeito do livro eletrônico. Entretanto a postura dos mesmos diante dos e-books no que diz respeito à iniciativa de compra, treinamento do pessoal, processamento técnico e instrução aos usuários varia bastante dentro do próprio sistema. A grande maioria se mostra favorável às vantagens oferecidas pelo livro eletrônico, mas ainda assim não há um consenso entre eles nem a congregação de esforços ou decisões colegiadas a respeito da demanda de usuários e da efetiva aquisição deste material. Algumas bibliotecas esperam a orientação e determinação do Sistema de Bibliotecas, enquanto outras já estão adquirindo livros eletrônicos. 
O uso efetivo e sistemático do livro eletrônico no Sistema de Bibliotecas da UFMG ainda provoca alguns questionamentos. De certo modo são dúvidas pertinentes, pois as bibliotecas ainda não possuem números expressivos de e-books incorporados no seu acervo e fazendo parte dos serviços rotineiros das bibliotecas, o que dificulta uma análise mais apurada e conclusiva. Apesar disso, a maioria dos bibliotecários mostra-se muito interessada em adquirir os livros eletrônicos, desde que a biblioteca e seus usuários sejam atendidos em suas necessidades reais. Ressaltam questões como segurança e garantia na aquisição dos e-books, assim como respeito aos direitos autorais.

Apesar de cada unidade apresentar uma realidade diferente, no que tange às vantagens e desvantagens do livro eletrônico as opiniões são bastante semelhantes. Foram apontadas em síntese como vantagens: o acesso multiusuário; simultâneo a um número indefinido de usuários, agilidade no processamento técnico; eliminação de problemas como livros esgotados, lista de reserva, multa e verba destinada para a conservação do acervo; facilidade na portabilidade, facilidades aos portadores de deficiência visual (sintetizadores de voz; textos com multimídia); a permissão à pesquisa integrada de links e conteúdos; a sustentabilidade, com alusão ao "ecologicamente correto", pois a eliminação de papéis preserva as árvores; a possibilidade de download e uso em qualquer lugar do mundo e a qualquer tempo; e o fato de solucionar problemas de espaço gerado pelo armazenamento do livro físico na biblioteca; além de eliminar problemas referentes a conservação e restauro. As desvantagens, por sua vez foram apontadas: maior consumo de energia; uma leitura mais cansativa e mais lenta; a necessidade de conhecimento da tecnologia aplicada; a obsolescência de equipamentos e formatos de arquivos.

Assim, percebe-se que os desafios não param por aqui. Apesar de serem muitas as vantagens oferecidas pelos livros eletrônicos, ao se deparar com as desvantagens, como a obsolescência dos equipamentos, e com as dificuldades relacionadas à aquisição dos e- 
books pelas bibliotecas, sente-se que ainda há muito que caminhar e pesquisar. Deve-se repensar algumas ofertas que parecem serem ideais, que afirmam serem ecologicamente corretas, mas que em nenhum momento apresentam, por exemplo, soluções para a questão do lixo eletrônico, em volume cada vez maior gerado pela tecnologia dos mais diferentes hardwares para a leitura do livro eletrônico.

Por fim, observa-se que não basta seguir o que o mercado está oferecendo, mas repensar as políticas da biblioteca e trabalhar em conjunto dentro do Sistema de Bibliotecas, buscando unir as novas tecnologias com a missão dos profissionais bibliotecários perante a comunidade da UFMG e da sociedade em geral.

Uma das respostas mais esperadas em toda a pesquisa era a tabulação da questão "Se um título acadêmico que você precisa da biblioteca estivesse disponível no formato impresso e no formato eletrônico, qual você escolheria para empréstimo?" O resultado foi um pouco surpreendente, pois entre os mais de 1500 alunos respondentes, observou-se que, apesar de $58 \%$ dos entrevistados declararem utilizar o livro eletrônico, $74 \%$ deles, se tivessem que escolher, iriam preferir o livro no formato impresso, e somente $26 \%$ prefeririam o livro em formato eletrônico.

Gráfico 13 - Formato de escolha do livro para empréstimo no Sistema de Bibliotecas

Formato eletrônico

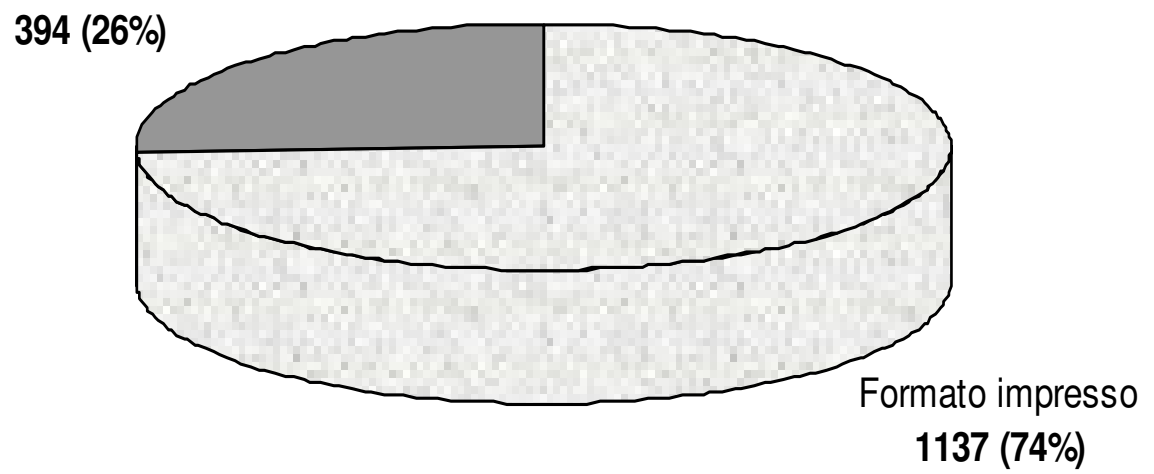

Fonte: Dados da pesquisa coletados em set-dez/2012. 
Gráfico 14 - Formato de escolha do livro para empréstimo por área de concentração

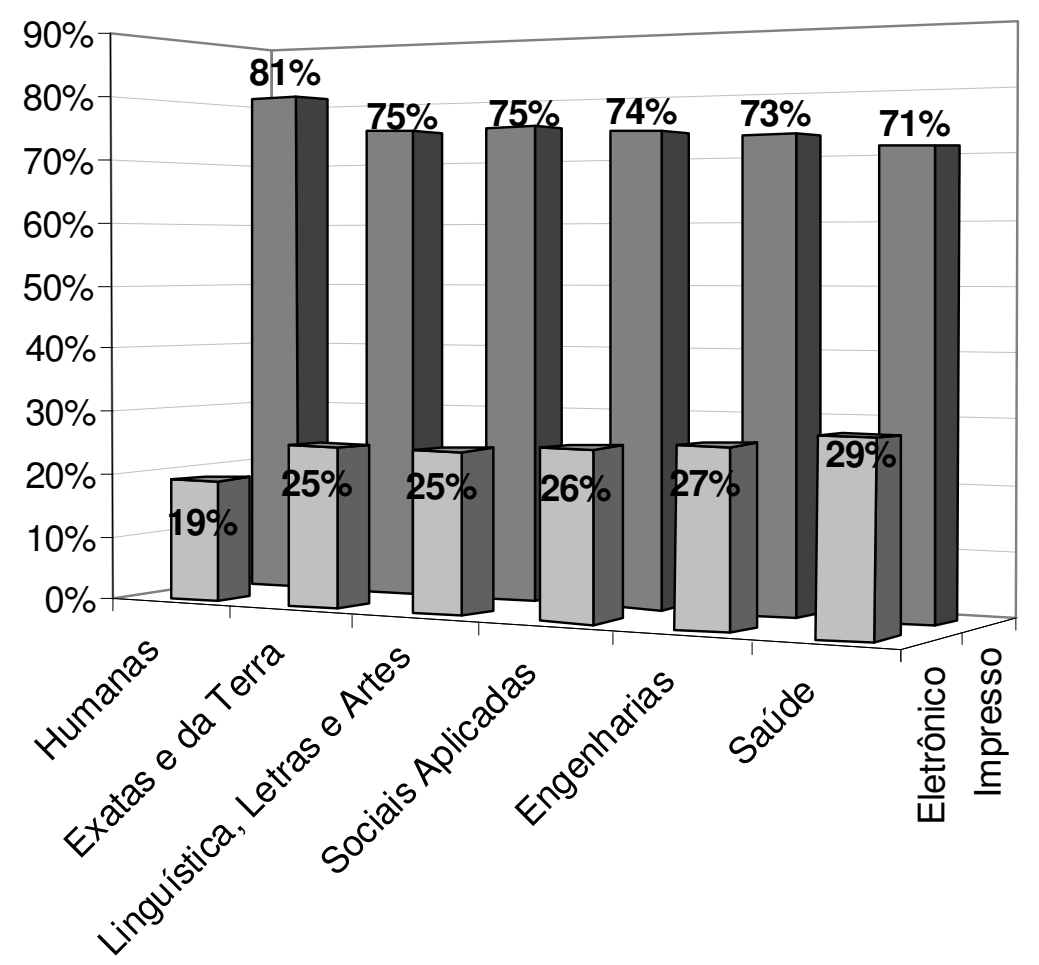

Fonte: Dados da pesquisa coletados em set-dez/2012.

Os alunos que mais valorizam o formato impresso são os alunos da área de Humanas e aqueles que apresentam maior aceitação ao formato eletrônico são os da área de Saúde, conforme demonstra o gráfico 14. De certo modo, esse resultado é coerente com o restante dos dados da pesquisa e da revisão de literatura, que vinham apontando que o livro impresso é preferido quando se trata de uma leitura capa a capa e o livro eletrônico é selecionado para as situações em que a leitura é fragmentada ou que tratam-se de pesquisas mais pontuais. Geralmente o tipo de leitura dos alunos das áreas de Humanas é prioritariamente capa a capa, o mesmo não ocorrendo com a área de saúde, em que os estudos e pesquisas típicas não refletem leituras que vão do início ao final de um título, mas que prendem-se a capítulos ou assuntos específicos. No entanto, acredita-se que os dados obtidos nessa pesquisa precisam ser melhor aprofundados para obter maior precisão nesse tipo de discussão. 
A certeza que fica é que, ainda que o serviço oferecido pelo Sistema de Bibliotecas da UFMG em termos de livro eletrônico esteja incipiente, seu público não tem demandado mais do que é oferecido. $A$ grande preferência do leitor da UFMG ainda é pelo livro impresso. Se por um lado o Sistema precisa se preocupar em se antecipar à demanda de seu público e aderir às inovações do mercado, por outro ainda há tempo para se fazer estudos e se adaptar com a cautela necessária para não se tomar decisões precipitadas.

\section{REFERÊNCIAS}

GIBBONS, Susan. Ebooks: some concerns and surprises. Libraries and the Academy, Baltimore, v. 1, n. 1, p. 71-75, jan. 2001.

LANDONI, Monica. Electronic books. In: FEATHER, John; STURGES, Paul. (Ed.). International encyclopedia of information and library science. 2. ed. London: Routledge, 2003. p. 168-71.

ROSSI, Luigi Canali. Lectores de libros electrónicos: tendencias y estadísticas de uso de los ebooks y libros digitales - informe Springer 2008. Disponível em:

<http://es.masternewmedia.org/2008/11/26/lectores_de_libros_electronic os_tendencias_y_estadisticas.htm>. Acesso em: 30 set. 2012.

SIMON, Erick J. Electronic textbooks: a pilot study of student e-reading habits. Future of Print Media Journal, Martin d'Heres, winter, 2001. Disponível em: <http://www.ericjsimon.com/papers/papers/ebook.pdf>. Acesso em 30 set. 2012.

TOWLE, Gemma. Ebooks: challenges and effects on the book chain. 2007. Tese (Doutorado em Ciência da Informação) - Loughborough University, Leicestershire, 2007. Disponível em: <https://dspace.lboro.ac.uk/dspacejspui/bitstream/2134/7980/3/479447.pdf>. Acesso em: 25 mar. 2013.

VASSILOU, Magda; ROWLEY, Jennifer. Progressing the definition of "ebook". Library Hi Tech, Ann Arbor, v. 26, n. 3, p. 355-368, 2008. 
VELASCO, Juliana; ODDONE, Nanci. O livro eletrônico na prática científica: estratégia metodológica. In: ENCONTRO NACIONAL DE PESQUISA EM CIÊNCIA DA INFORMAÇÃO, 8., 2007, Salvador.

Anais... Salvador, 2007. Disponível em: $<$ www.enancib.ppgci.ufba.br/artigos/GT7--069.pdf>. Acesso em: 25 mar. 2013.

WILSON, Ruth; LANDONI, Monica. Evaluating electronic textbooks: a methodology. In: EUROPEAN CONFERENCE, 5., 2001, Darmstadt. Proceedings... Darmstadt, 2001. Disponível em: <http://strathprints.strath.ac.uk/1904/1/strathprints001904.pdf>. Acesso em: 25 mar. 2013.

\section{Title}

Electronic book and its use by undergraduate students of a federal university

\section{Abstract}

Introduction: Electronic books (e-books) has been gaining notoriety in the market and in academic research. University libraries bet on loan contents, and do not believe on borrow devices for reading purposes.

Purpose: Presents the results of a research carried out with undergraduate students and librarians of the Library System of Universidade Federal de Minas Gerais - UFMG designed to investigate how the students are using e-books and e-readers and if the library system is prepared to provide support in terms of services and collections.

Methodology: Regarding the methodology, the research was conducted in three steps including literature review, qualitative research with librarians (conducting interviews) and quantitative research with students (questionnaires).

Results: The main results show that over $50 \%$ of students have made use of ebooks but about $75 \%$ prefer the p-books to perform their activities of reading and research. The main format used is PDF. The most used features include changing the font size, underline, consult the dictionary and annotate. The provision of e-books by the Library System of UFMG is still limited and occurs through isolated initiatives by units. Librarians point out advantages and disadvantages of e-book usage.

Conclusions: The public has not demanded more than it is been offered. Given the choice, the vast preference of UFMG reader is still the book in the printed version.

Keywords: E-book. P-book. University library. Library system of the Federal University of Minas Gerais. 


\section{Titulo}

Libro electrónico y su uso por estudiantes universitarios de una universidad federal

\section{Resumen}

Introducción: Los libros electrónicos (e-books) ha ido ganando notoriedad en el mercado y en la investigación académica. Las bibliotecas universitarias apuestan en los prestamos de contenidos y no creen en el préstamo de dispositivos de lectura.

Objetivos: Presenta los resultados de la investigación llevada a cabo con estudiantes universitarios y bibliotecarios del Sistema de Bibliotecas de la Universidad Federal de Minas Gerais - UFMG diseñado para investigar cómo los estudiantes utilizan los libros electrónicos y si el sistema de bibliotecas está dispuesto a proporcionar apoyo en términos de servicios y colecciones.

Metodología: La metodología de la investigación se realizó en tres etapas que comprenden revisión de la literatura, la investigación cualitativa con los bibliotecarios (entrevistas) y la investigación cuantitativa con los estudiantes (cuestionarios).

Resultados: Los principales resultados muestran que más del $50 \%$ de los estudiantes han hecho uso de los libros electrónicos, pero aproximadamente el $75 \%$ prefieren el libro impreso para realizar sus actividades de la lectura y la investigación. El formato más utilizado es el PDF y las características más usadas incluyen cambiar el tamaño de fuente, acentuar, consultar el diccionario y tomar notas. La provisión de libros electrónicos por el Sistema de Bibliotecas de la UFMG es aún limitada y se produce de forma descoordinada, a través de iniciativas aisladas de las unidades. Los bibliotecarios señalan las ventajas y desventajas del uso de libros electrónicos.

Conclusiones: El público no ha exigido más de lo que se ofrecía. Dada la elección, la gran preferencia de los lectores de la UFMG está todavía en el libro impreso.

Palabras clave: Libro electrónico. E-book. Biblioteca universitaria. Sistema de Bibliotecas de la Universidad Federal de Minas Gerais.

Recebido em: 01/06/2014

Aceito em: 10/05/2015 